\title{
Pengetahuan, Sikap dan Kepemilikan KMS terhadap Kunjungan Ibu ke Posyandu Baktijaya Depok
}

\author{
Aletha Ayu, Yanti Harjono, Aulia Chairani \\ Fakultas Kedokteran Universitas Pembangunan Nasional "Veteran" Jakarta \\ Departemen Ilmu Kesehatan Masyarakat Fakultas Kedokteran Universitas Pembangunan \\ Nasional "Veteran" Jakarta
}

\begin{abstract}
Abstrak
Latar belakang : Upaya penurunan Angka Kematian Bayi (AKB) dan Angka Kematian Anak Balita (AKABA) melalui Posyandu sebagai dukungan masyarakat dalam mencapai indicator pembangunan kesehatan nasional. Posyandu Baktijaya Depok belum mencapai target untuk partisipasi kunjungan balita ke posyandu dan kepemilikan KMS (Kartu Menuju Sehat) juga masih rendah dan perlu ditingkatkan. Penelitain ini ditujukan untuk menilai hubungan pengetahuan dan sikap ibu terhadap posyandu, serta kepemilikan KMS sebagai pemantau pertumbuhan dan perkembangan anak.

Metode: Penelitian ini menggunakan desain cross sectional pada ibu yang dengan balita berusia 0-59 bulan. Sampel sebanyak 214 ibu dipilih secara Proportionate Stratified Random Sampling. Wawancara dilakukan menggunakan kuesioner, observasi kartu KMS dan buku register Posyandu untuk variabel pengatahuan, sikap, dan kepemilikan KMS. Uji Kai Kuadrat digunakan untuk menilai hubungan antar dua variabel.

Hasil: Total 214 subjek menunjukkan pengetahuan cukup (49,1\%), sikap baik (65,4\%) dan kepemilikan KMS tinggi (89,7\%). Uji Kai Kuadrat menemukan signifikansi terhadap pengetahuan ( $p=0,007)$, sikap ibu $(p=0,000)$, dan kepemilikan KMS dengan kunjungan ke Posyandu $(p=0,000)$.

Kesimpulan: Ditemukan hubungan antara pengetahuan ibu, sikap ibu, dan kepemilikan KMS terhadap kunjungan ke Posyandu.
\end{abstract}

Kata kunci : Balita, Kartu Menuju Sehat, Pengetahuan, Posyandu, Sikap

\section{Knowledges, Attitudes and “KMS” Ownership to Mothers's Visiting Posyandu Baktijaya Depok}

\begin{abstract}
Background: Efforts to reduce the Infant Mortality Rate (IMR) and the Infant Mortality Rate (AKABA) through Posyandu as community support in achieving national health development indicators. Posyandu Baktijaya Depok has not yet reached the target for toddlers' participation in posyandu visits and low KMS (Kartu Menuju Sehat) ownership which needs to be improved. This study aimed to assess the relationship between knowledge and attitudes of mothers towards posyandu, as well as ownership of KMS as a monitor for children's growth and development.

Methods: A cross sectional study was performed among mothers with toddlers aged 0-59 months. A sample of 214 mothers were selected by means of Proportionate Stratified Random Sampling. Interviews were conducted using questionnaires, observation of KMS and Posyandu register books for the variables of knowledge, attitudes, and KMS ownership. Chi Square test was used to assess the relationship between two variables.

Results: A total of 214 subjects showed sufficient knowledge (49.1\%), good attitude (65.4\%) and high KMS ownership (89.7\%). The Chi Square test showed significance for knowledge $(p=0.007)$, maternal attitudes $(p=0.000)$, and KMS ownership with visits to Posyandu $(p=0.000)$.

Conclusion: There was a relationship between maternal knowledge, maternal attitudes, and KMS ownership of visits to Posyandu.

Keywords: Toddler, Card Towards Health, Knowledge, Posyandu, Attitude
\end{abstract}

Korespondensi: Aulia Chairani

Email : auliachairani@upnvj.ac.id /

dr.aulia.chairani@gmail.com 


\section{PENDAHULUAN}

Kesehatan merupakan salah satu indicator pembangunan kesejahteraan kependudukan. Penurunan Angka Kematian Bayi (AKB) dan Angka Kematian Balita (AKABA) merupakan target nasional karena termasuk indicator dalam pembangunan kesehatan. Di Indonesia $\mathrm{AKB}$ data Kemenkes terbaru masih tinggi dan ditargetkan turun menjadi 24 dari nilai 32 per 1000 kelahiran hidup, sedangkan AKI di tahun 2015 masih mencapai 305 per 100.000 kelahiran hidup masih tiga kali nilai yang ditargetkan yaitu 102 per 100.000 kelahiran hidup.sedangkan AKABA juga masih ditargetkan turun dari nilai 40 dari data sebelumnya. ${ }^{1}$ Pemerintah Indonesia telah melakukan beberapa upaya untuk menurunkan AKB dan AKABA yang diarahkan dalam peningkatan kualitas pelayanan kesehatan seperti dengan dilakukannya revitalisasi dan optimalisasi Posyandu di seluruh Indonesia sejak tahun 2005.

Posyandu dibentuk dengan berdasarkan pada pemberdayaan masyarakat di bidang kesehatan yang dikelola dan untuk masyarakat dengan kegiatan utama pelayanan kesehatan ibu dan anak seperti pemantauan pertumbuhan dan perkembangan balita, pelayanan $\mathrm{KB}$, penyuluhan, dan konseling. ${ }^{2}$ Bentuk partisipasi masyarakat berkunjung ke Posyandu dikenal dengan istilah $\mathrm{D} / \mathrm{S}$. D/S adalah persentase balita yang ditimbang berat badannya di seluruh posyandu dibagi semua balita yang melapor ke seluruh posyandu disuatu wilayah kerja dan di dalam kurun waktu tertentu x $100 \%$.

Sejak tahun 2010 hingga 2014, terjadi peningkatan cakupan penimbangan balita di Indonesia tetapi menurun $73 \%$ di tahun $2015 .^{3}$ Angka tersebut masih rendah dari target Rencana Strategi (Renstra) tahun 2015-2019 yaitu indikator presentase realisasi kegiatam administrasi dan dukungan pelaksanaan tugas Program Bina Gizi dan KIA sebanyak $94 \% .^{4}$

Menurut Pusat Data dan Informasi Kemenkes RI, kurangnya tingkat kunjungan ibu ke Posyandu menyebabkan meningkatnya kasus tumbuh kembang anak yang tidak terpantau dan terdeteksi secara dini. Di Indonesia saat ini terdapat 4,5 juta balita yang mengalami gizi buruk maupun gizi kurang, tetapi belum terdeteksi, diantaranya pada balita di provinsi Jawa Barat yang menempati peringkat tertinggi sebesar 674.331 balita. ${ }^{5}$ Sedangkan di Kota Depok, menurut data penimbangan balita tahun 2014 terdapat 268 balita dengan berat badan dibawah garis merah (BGM) di Posyandu wilayah kerja Puskesmas Baktijaya Depok yang berjumlah 29 Posyandu. ${ }^{6}$ Sejak tahun 2014, cakupan penimbangan balita di Kota Depok masih jauh dari target Renstra sebesar 58\%. ${ }^{7}$

Hal tersebut dapat berkaitan dengan perilaku masyarakat untuk berpartisipasi dalam kegiatan Posyandu. Perilaku tersebut dilatar belakangi oleh beberapa faktor diantaranya usia, tingkat pendidikan, pengetahuan, sikap, jarak tempuh ke posyandu, sarana dan prasarana, program PMT, kepemilikan KMS, dorongan keluarga dan petugas kesehatan. Kesadaran ibu untuk berkunjung ke Posyandu dapat didorong oleh pengetahuan yang cukup baik, sikap yang baik dan tersedianya sarana seperti Kartu Menuju Sehat/ Buku KIA. ${ }^{8}$ Terdapat 5 variabel yang berhubungan dengan perilaku kunjungan ke Posyandu yaitu Pendidikan ibu lebih rendah dari SMP, pengetahuan baik, sikap positif, memiliki kartu menuju sehat (KMS) serta membutuhkan pelayanan Posyandu. ${ }^{9}$ Berdasarkan masih rendahnya cakupan kunjungan ke Posyandu di Indonesia untuk memantau pertumbuhan bayi dan balita yang dapat dilihat dari data penimbangan, peneliti tertarik untuk mengetahui keterkaitan antara pengetahuan, sikap ibu dan kepemilikan KMS balita dengan perilaku Kunjungan ke Posyandu di Posyandu kelurahan Baktijaya Depok tahun 2017.

\section{METODE}

Studi cross sectional ini dilakukan di posyandu yang berada di bawah Puskesmas Baktijaya Depok pada selama Februari hingga Maret 2017. Sampel sebanyak 214 orang merupakan ibu dengan balita di Posyandu wilayah kerja Puskesmas Baktijaya.

Kriteria inklusi yaitu ibu yang berdomisili di wilayah kerja Puskesmas Baktijaya, memiliki balita usia 0-59 bulan, balita terdaftar di buku register Posyandu. Sedangkan akan dieksklusi jika tidak bersedia ikut dalam penelitian. Sampel dipilih secara acak menggunakan teknik proportionate stratified random sampling dari 29 posyandu di Puskesmas Baktijaya. Data dikumpulkan melalui wawancara menggunakan kuesioner yang diisi langsung oleh para ibu di setiap posyandu dan dengan melihat serta mendata kunjungan ke Posyandu melalui Kartu Menuju Sehat (KMS) dan buku register 
Posyandu. Seluruh variabel dianalisis menggunakan uji chi-square.

\section{HASIL}

Hasil penelitian menunjukkan sebagian besar berada dalam kelompok usia 20 - 30 tahun (48,1\%), Ibu Rumah Tangga (IRT) (83,6\%), balitanya berusia $12-23$ bulan $(32,2 \%)$ dan jenis kelamin balitanya adalah perempuan $(55,6 \%)$. Tabel 1 menunjukkan pengetahuan yang cukup $(49,1 \%)$, sikap yang baik terhadap Posyandu $(65,4 \%)$, memiliki KMS Balita $(89,7 \%)$,dan tingginya partisipasi aktif berkunjung ke Posyandu $(74,3 \%)$.

Tabel 1. Distribusi variabel yang mempengaruhi kunjungan ibu di Posyandu Kelurahan Baktijaya Depok

\begin{tabular}{|c|c|c|}
\hline Variabel & Frekuensi & Persentase \\
\hline \multicolumn{3}{|l|}{ Pengetahuan } \\
\hline Baik & 65 & $30,4 \%$ \\
\hline Cukup & 105 & $49,1 \%$ \\
\hline Kurang & 44 & $20.6 \%$ \\
\hline \multicolumn{3}{|l|}{ Sikap } \\
\hline Baik & 140 & $65,4 \%$ \\
\hline Cukup & 73 & $34,1 \%$ \\
\hline Kurang & 1 & $0,5 \%$ \\
\hline \multicolumn{3}{|l|}{ Kepemilikan KMS } \\
\hline Punya & 192 & $89,7 \%$ \\
\hline Tidak punya & 22 & $10,3 \%$ \\
\hline \multicolumn{3}{|l|}{ Kunjungan Ibu } \\
\hline Aktif & 159 & $74,3 \%$ \\
\hline Tidak Aktif & 55 & $25,7 \%$ \\
\hline Total & 214 & $100 \%$ \\
\hline
\end{tabular}

Hasil analisis bivariat pada variabel pengetahuan dengan variabel kunjungan ke Posyandu didapatkan bahwa persentase kunjungan aktif di tiap tingkat pengetahuan lebih tinggi dibanding dengan ibu yang tidak aktif. Proporsi kunjungan aktif juga berbanding lurus dengan peningkatan pengetahuan. Analisis Chi Square didapatkan nilai p 0,007 sehingga terdapat hubungan antara pengetahuan dengan kunjungan ke Posyandu. Hasil tersebut menunjukkan bahwa proporsi kunjungan aktif di setiap tingkatan sikap lebih tinggi dibandingkan dengan kategori kunjungan tidak aktif. Begitu pula proporsi kunjungan aktif semakin meningkat jika sikap ibu terhadap posyandu baik. Uji statistik didapatkan nilai $\mathrm{p}=0,0001$ sehingga disimpulkan adanya hubungan yang signifikan antara sikap dengan kunjungan Posyandu.

Tabel 2. Tabulasi silang variabel yang mempengaruhi kunjungan ibu di Posyandu Kelurahan Baktijaya Depok

\begin{tabular}{|c|c|c|c|c|c|c|c|}
\hline \multirow{3}{*}{ Sikap } & \multicolumn{4}{|c|}{ Kunjungan Posyandu } & \multirow{2}{*}{\multicolumn{2}{|c|}{ Total }} & \multirow{3}{*}{ p-value } \\
\hline & \multicolumn{2}{|c|}{ Tidak Aktif } & \multicolumn{2}{|c|}{ Aktif } & & & \\
\hline & $\mathbf{N}$ & $\%$ & $\mathbf{N}$ & $\%$ & \multicolumn{2}{|c|}{$\%$} & \\
\hline$\overline{\text { Cukup + Kurang }}$ & 35 & 47,3 & 39 & 52,7 & \multicolumn{2}{|c|}{100} & \multirow[t]{2}{*}{0,000} \\
\hline Baik & 20 & 14,3 & 120 & 85,7 & 140 & & \\
\hline \multirow{3}{*}{ Pengetahuan } & \multicolumn{4}{|c|}{ Kunjungan Ibu } & \multirow{2}{*}{\multicolumn{2}{|c|}{ Total }} & \multirow{3}{*}{ p-value } \\
\hline & \multicolumn{2}{|c|}{ Tidak Aktif } & \multicolumn{2}{|c|}{ Aktif } & & & \\
\hline & $\mathbf{N}$ & $\%$ & $\mathbf{N}$ & $\%$ & $\mathrm{~N}$ & $\%$ & \\
\hline Kurang & 19 & 43,2 & 25 & 56,8 & 44 & 100 & 0,007 \\
\hline Cukup & 25 & 23,8 & 80 & 76,2 & 105 & 100 & \\
\hline Baik & 11 & 16,9 & 54 & 83,1 & 65 & 100 & \\
\hline
\end{tabular}


Hasil analisis hubungan antara kepemilikkan KMS dengan kunjungan Posyandu didapatkan bahwa responden yang memiliki KMS akan semakin aktif berkunjung ke Posyandu, dan responden yang tidak memiliki KMS menunjukkan persentase tidak aktif yang lebih tinggi. Berdasarkan hasil uji statistik diperoleh nilai $P$-value $0,000(\mathrm{P}<0,05)$, sehingga dapat disimpulkan bahwa ada hubungan yang bermakna antara kepemilikan KMS dengan kunjungan posyandu.

Tabel 3. Tabulasi Silang Kepemilikan KMS Ibu dengan Kunjungan Ibu Balita di Posyandu Kelurahan Baktijaya Depok

\begin{tabular}{lcccccccc}
\hline \multirow{2}{*}{ Kepemilikan KMS } & \multicolumn{4}{c}{ Kunjungan Ibu } & \multirow{2}{*}{ Total } & \multirow{2}{*}{ Nilai p } \\
\cline { 2 - 6 } & \multicolumn{2}{c}{ Tidak Aktif } & \multicolumn{2}{c}{ Aktif } & & \\
\cline { 2 - 7 } & $\mathbf{N}$ & $\mathbf{\%}$ & $\mathbf{N}$ & $\mathbf{\%}$ & $\mathbf{N}$ & $\%$ & \\
\hline Tidak punya & 21 & 95,5 & 1 & 4,5 & 22 & 100 & 0,000 \\
Punya & 34 & 17,7 & 158 & 82,3 & 192 & 100 & \\
\hline
\end{tabular}

\section{PEMBAHASAN}

Penelitian ini menemukan sebagian besar ibu di Kelurahan Baktijaya Depok berpengetahuan baik terhadap pentingnya kunjungan ke Posyandu. Hasil tersebut kemungkinan didukung dengan kemudahan akses informasi antar sesama ibu dengan balita, media elektronik, media cetak, atau pengumuman dari lingkungan tempat tinggal. Sebagian besar pengetahuan tersebut diperoleh mata dan telinga. ${ }^{10}$ Sesuai dengan temuan Rachmawati, proporsi ibu yang membawa balitanya ke Posyandu sebagian besar berpengetahuan cukup. ${ }^{8}$ Hasil penelitian ini juga sejalan dengan penelitian Putri dkk dan Suharti bahwa rerata responden yang berkunjung ke Posyandu memiliki pengetahuan yang cukup baik. ${ }^{11,12}$

Sebagian besar ibu dalam penelitian ini menunjukkan sikap positif terhadap kegiatan posyandu Kelurahan Baktijaya Depok. Sikap baik tersebut mungkin bisa timbul karena adanya pengaruh dan ajakan teman sebaya, keluarga, tokoh masyarakat atau petugas kesehatan lainnya. Sikap muncul dipengaruhi oleh stimulus tertentu menghasilkan respon emosional terhadap kehidupan sehingga sikap merupakan kecenderungan untuk beraktivitas atau bertindak yang posisinya di bawah tindakan. ${ }^{12}$ Dalam konteks ini, sikap berupa suatu bentuk kesiapan bereaksi tehadap objek di sekitarnya sebagai suatu penghayatan. ${ }^{13}$ Hasil penelitian sejalan dengan penelitian Suharti bahwa persentase responden yang berkunjung ke Posyandu memiliki sikap yang baik atau mendukung yaitu sebanyak 37 responden $(54,4 \%)^{12}$, namun hasil penelitian ini berbeda dengan penelitin Putri dkk. bahwa distribusi ibu yang aktif berkunjung ke Posyandu justru sikap negatif yang lebih tinggi. ${ }^{11}$

Responden pada penelitian ini mayoritas memiliki KMS karena diberikan dari Puskesmas atau dari pelayanan kesehatan lainnya sebagai media informasi dan penyuluhan gizi pada ibu dan balita. KMS merupakan salah satu kartu catatan pelayanan kesehatan yang wajib disimpan di rumah dan dibawa setiap datang ke tempat pelayanan kesehatan untuk. ${ }^{14}$ Temuan dalam penelitian ini sesuai dengan penelitian dari Suryaningsih dan Hairunida bahwa proporsi kepemilikan KMS lebih tinggi ditemukan pada ibu yang membawa balitanya ke Posyandu dibanding yang tidak memiliki. 9,15 KMS merupakan salah satu bentuk sarana dalam pelayanan kesehatan anak terutama usia balita. Namun, berbeda dengan penelitian Putri dkk yang melaporkan mengatakan bahwa proporsi berdasarkan sarana dan prasarana yang buruk lebih tinggi (54\%). ${ }^{11}$

Secara umum hasil penelitian menunjukan bahwa responden aktif berkunjung ke posyandu. Hal ini menandakan bahwa partisipasi masyarakat di Kelurahan Baktijaya Depok dalam kegiatan Posyandu sudah cukup baik. Cukup tingginya partisipasi masyarakat di Kelurahan Baktijaya Depok ini dapat terjadi karena tingginya upaya dari petugas kesehatan dalam melayani, menciptakan komunikasi aktif dengan para warga untuk mengunjungi Posyandu, pengetahuan dan sikap baik dari para ibu, dan dukungan keluarga. Perilaku positif tersebut merupakan bentuk respon individual terhadap sistem pelayanan kesehatan berupa pengetahuan, persepsi, sikap dan penggunaan fasilitas, petugas dan obat-obatan. ${ }^{16}$ Serupa dengan Suryaningsih, 
penelitian ini juga menemukan bahwa persentasi responden bekunjung ke posyandu yang aktif lebih tinggi sebesar 83,1\% dibandingkan yang tidak aktif ${ }^{15}$, namun proporsi penelitian ini tidak menunjukkan sejalan dengan penelitian Hairunida yang menemukan tingginya $(60,1 \%)$ ibu yang mempunyai perilaku kunjungan Posyandu yang kurang. ${ }^{9}$

Hasil uji statistik menunjukkan bahwa pengetahuan ibu mempengaruhi perilaku kunjungan ibu ke Posyandu. Hasil tersebut konsisten dengan temuan Indria dan Rivqoh bahwa pengetahuan ibu tentang Posyandu mempengaruhi konsistensi kunjungan ke Posyandu. ${ }^{17}$ Sesuai dengan teori perilaku yang menyatakan pengetahuan sangat diperlukan dalam membentuk perilaku seseorang. ${ }^{13}$ Menurut teori Green dalam Notoatmodjo, perilaku ditentukan oleh tiga faktor yakni faktor pemungkin (enabling factor), faktor penguat (reinforcing factor) dan faktor pendorong (predisposing factor). ${ }^{18}$ Pengetahuan adalah salah satu faktor pembentuk perilaku yang terdapat dalam faktor pendorong (predisposing).

Penelitian ini menunjukan tingkat pengetahuan yang semakin baik dapat meningkatkan keaktifan kunjungan ke Posyandu karena pengetahuan yang tercakup dalam domain kognitif memiliki tingkatan. ${ }^{13}$ Pengetahuan terjadi jika seseorang mengingat suatu materi yang telah dipelajarinya, kemudian dapat menjelaskan secara benar tentang objek yang diketahuinya akan menguasai kemampuan memanfaatkan materi yang dipelajarinya dalam kondisi sebenarnya. Aplikasi ini dapat terlihat wujudnya dari tindakan seseorang. Pengetahuan yang sudah didapatkan seseorang tersebut membuat ia lebih paham dan mampu serta mendukung untuk melakukan suatu tindakan. Kontras dengan temuan Nixen Rachmawati yang menunjukkan tidak ada keterkaitan antara pengetahuan ibu tentang Posyandu dengan perilaku kunjungan ke Posyandu di Desa Geneng Sentul Sidoagung Godean Sleman. ${ }^{8}$

Uji statistik juga menunjukkan bahwa sikap signifikan terhadap kunjungan ke Posyandu. Sesuai dengan penelitian Putri dkk yang juga melaporkan hubungan sikap ibu balita dengan kunjungan ke Posyandu. ${ }^{11}$ Pemikiran ibu bahwa membawa balitanya ke Posyandu merupakan hal yang positif, baik, dan bentuk persetujuan terhadap manfaat Posyandu. Hal tersebut adalah perwujudan dari sikap. Sikap ibu dalam perilaku kunjungan ke Posyandu sebagai akumulasi pemikiran bahwa berkunjung ke
Posyandu adalah hal yang baik, positif, dan setuju terhadap manfaat Posyandu. ${ }^{12}$ Hal ini dapat dipengaruhi oleh teman-teman responden, keaktifan kader serta petugas puskesmas dalam pendekatan secara persuasif, penyuluhan, melakukan sweeping tentang kegiatan posyandu yang membuat responden memiliki reaksi yang baik. Dalam hal ini, sikap merupakan kesiapan bereaksi terhadap objek di sekitarnya sebagai bentuk penghayatan yang dibagi menjadi tiga domain pokok yaitu kepercayaan, ilham, dan konsep kehidupan emosional terhadap suatu objek dan kecenderungan untuk bertindak. ${ }^{13}$ Suatu sikap akan menjadi perbuatan yang nyata bila terdapat faktor pendukung seperti fasilitas atau dukungan dari lainnya. Jika seseorang mendapatkan stimulus kesehatan, kemudian berpendapat sesuai yang dia ketahui, selanjutnya diharapkan dia akan mempraktikan hal yang disikapinya tersebut. Inilah perilaku kesehatan (overt behavior) yang dapat dilihat dari sikap baik terhadap Posyandu dapat membuat ibu-ibu dari penelitian ini mempraktikannya dengan berkunjung ke Posyandu. Berlawanan terhadap penelitian Sambas yang menyatakan tidak ada keterkaitan sikap dengan kunjungan ibu balita ke Posyandu. ${ }^{19}$

Analisis bivariat didapatkan signifikansi antara kepemilikan KMS dengan kunjungan ke Posyandu. Konsisten dengan temuan Suryaningsih bahwa ibu yang memiliki buku KIA/KMS akan cenderung rutin membawa balitanya ke Posyandu. ${ }^{15}$ Menurut teori Green dalam Notoatmodjo faktor pemungkin (enabling factor) dalam pembentukan perilaku, terdapat sarana yang memberikan kontribusi terhadap tindakan seseorang. ${ }^{18}$ Ibu yang memiliki KMS akan semakin aktif berkunjung ke Posyandu, sedangkan rendahnya kunjungan ke Posyandu ditunjukkan oleh ibu yang tidak memiliki KMS. Hal ini dikuatkan oleh pendapat Sambas bahwa kelengkapan sarana akan mendukungan individu untuk memanfaatkan sebaik-baiknya sarana tersebut. ${ }^{19}$ Kepemilikkan KMS cenderung mendorong ibu untuk mengunjungi Posyandu danperasaan termotivasi melihat catatan kesehatan anaknya. Namun, kontras dengan penelitian Putri dkk yang tidak menemukan signifikansi antara sarana dan prasarana (timbangan/dacin, alat ukur TB, thermometer, pemberian makanan tambahan anak serta fasilitas bermain di posyandu) dengan rutinitas kunjungan ibu balita ke Posyandu. ${ }^{11}$

\section{KESIMPULAN}


Sebagian besar ibu balita Posyandu Baktijaya memiliki kunjungan yang aktif, pengetahuan cukup, sikap baik terhadap posyandu, dan memiliki KMS. Pada penelitian ini terdapat hubungan positif antara pengetahuan, sikap dan kepemilikan KMS terhadap kunjungan ibu yang memiliki bayi dan balita ke Posyandu Baktijaya.

\section{DAFTAR PUSTAKA}

1. Kemenkes RI. Profil Kesehatan Indonesia 2019. Jakarta : Kementerian Kesehatan RI; 2019

file:///C:/Users/Administrator/Downloads/Pr ofil-Kesehatan-indonesia-2019.pdf

2. Kemenkes RI. Pedoman Umum Pengelolaan Posyandu. Jakarta : Kementerian Kesehatan RI; 2011

3. Kemenkes RI. Profil Kesehatan Indonesia 2015. Jakarta : Kementerian Kesehatan RI; 2016

4. Kemenkes RI. Rencana Strategis Kementerian Kesehatan tahun 2015-2019. Jakarta : Kementerian Kesehatan RI; 2019 file:///C:/Users/Administrator/Downloads/06 07_Rencana\%20Strategis\%20Kementerian \%20Kesehatan\%20Tahun\%202015-2019.pd $\underline{\mathrm{f}}$

5. Kemenkes RI. Situasi dan Analisis Gizi. Jakarta : Kementerian Kesehatan RI; 2014

6. Dinkes Depok. Resume Profil Kesehatan Kota Depok Tahun 2014. Depok : Dinas Kesehatan Kota Depok; 2014

7. Dinkes Depok. Profil Kesehatan Kota Depok Tahun 2016. Depok : Dinas Kesehatan Kota Depok; 2017 file:///C:/Users/Administrator/Downloads/32 76 Jabar Kota Depok 2016.pdf=

8. Rachmawati, N. Hubungan Pengetahuan Tentang Posyandu Dengan Perilaku Kunjungan ke Posyandu Pada Ibu Yang Mempunyai Balita di Desa Geneng Sentul Sidoagung Godean Sleman Tahun 2012 [Skripsi]. Yogyakarta: Sekolah Tinggi Ilmu Kesehatan Aisyiyah; 2012.

9. Hairunida, E. Faktor-faktor Yang Berhubungan Dengan Perilaku Kunjungan ke Posyandu Pada Ibu Balita di Wilayah Kerja Puskesmas Pancoran Mas Kota Depok Tahun 2012 [Skripsi]. Depok: Universitas Indonesia; 2012

10. Maulana, HDJ. Promosi Kesehatan. Jakarta: EGC; 2009.
11. Putri, MD, Junaid, H, Lisnawati. Hubungan Faktor Perilaku Ibu Balita Dengan Kunjungan ke Posyandu di Wilayah Kerja Puskesmas Mokoau Tahun 2015. Jurnal Ilmiah Mahasiswa Kesehatan Masyarakat. 2016;1(3)

12. Suharti, E. Hubungan Faktor Pengetahuan, Sikap, dan Dukungan Keluarga Dengan Perilaku Kunjungan ke Posyandu Pada Ibu Pekerja di Banjarnegara Jawa Tengah Tahun 2012 [Skripsi]. Depok: Universitas Indonesia; 2012

13. Notoatmodjo, S. Promosi Kesehatan dan Perilaku Kesehatan Edisi Revisi 2012. Jakarta: Rineka Cipta; 2012

14. Kemenkes RI. Buku Kesehatan Ibu dan Anak. Jakarta: Kementerian Kesehatan RI; 2015

15. Suryaningsih, H. Faktor-faktor Yang Berhubungan Dengan Perilaku Kunjungan Ibu Bayi dan Balita ke Posyandu di Puskesmas Kemiri Muka Kota Depok Tahun 2012 [Skripsi]. Depok: Universitas Indonesia; 2012

16. Dewi, M \& Wawan, A. Teori \& Pengukuran Pengetahuan Sikap Dan Perilaku Manusia. Yogyakarta: Nuha Medika; 2010

17. Indria \& Rivqoh. Hubungan Pengetahuan Ibu Tentang Posyandu Dengan Keteraturan Ibu Mengunjungi Posyandu di Desa Ciibeber RW 14 Puskesmas Cibeber Tahun 2014. Jurnal Kesehatan Kartika. 2011 Okt;07(50)

18. Notoatmodjo, S. Promosi Kesehatan Teori dan Aplikasi. Jakarta: Rineka Cipta; 2005

19. Sambas, G. Faktor-faktor Yang Berhubungan Dengan Kunjungan Ibu-ibu Anak Balita ke Posyandu di Kelurahan Bojongserang Kab. Cianjur Tahun 2002 [Tesis]. Depok: Universitas Indonesia; 2002 